\title{
SPATIAL AND TEMPORAL PATTERNS OF BIRD SPECIES DIVERSITY IN THE PANTANAL OF MATO GROSSO, BRAZIL: IMPLICATIONS FOR CONSERVATION
}

\author{
FIGUEIRA, J. E. C. ${ }^{1}$, CINTRA, R. ${ }^{2}$, VIANA, L. R. ${ }^{3}$ and YAMASHITA, C. ${ }^{4}$ \\ ${ }^{1}$ Departamento de Biologia Geral, Instituto de Ciências Biológicas, Universidade Federal de Minas Gerais, \\ C. P. 486, CEP 30161-970, Belo Horizonte, MG, Brazil \\ ${ }_{2}^{2}$ Departamento de Ecologia, Instituto Nacional de Pesquisas da Amazônia, Av. André Araújo, 2936, Petrópolis, \\ CEP 69083-000, Manaus, AM, Brazil \\ ${ }^{3}$ Departamento de Zoologia, Instituto de Ciências Biológicas, Universidade Federal de Minas Gerais, \\ CEP 30161-970, Belo Horizonte, MG, Brazil \\ ${ }^{4}$ Instituto Brasileiro de Meio Ambiente e Recursos Naturais Renováveis - IBAMA, \\ Gerencia de São Paulo, Núcleo de Fauna, Alameda Tiete, 637, CEP 01417-020, São Paulo, SP \\ Correspondence to: José Eugênio Cortes Figueira, Depto. Biologia Geral, Instituto de Ciências Biológicas, \\ Universidade Federal de Minas Gerais, C. P. 486, CEP 30161-970, Belo Horizonte, MG, \\ e-mail: cortes@mono.icb.ufmg.br \\ Received November 19, 2003 - Accepted August 19, 2004 - Distributed May 31, 2006 \\ (With 4 figures)
}

\begin{abstract}
Analysis of a three-year bird survey in the pantanal of Poconé revealed that most of the resident and seasonal birds are habitat generalists, using two or more habitats. In this study, previously sampled habitats were ranked in relation to species richness and stability (as measured by the ratio of seasonal to resident species). In all, nine habitats were grouped into three categories; results are as follows: 1) forests: more species-rich and more stable; 2) cerrado: intermediate levels; and 3) aquatic: less species-rich and less stable. The number of seasonal species remained relatively constant in forests throughout the year, while increasing in the other habitats during the dry season. The abundance of resident species seems to be related to species use of multiple habitats. Although many species were found to be habitat generalists, we discuss possible consequences of habitat loss and other human impacts on efforts to conserve this important bird community.
\end{abstract}

Keywords: flooding cycle, habitat heterogeneity, habitat stability, species abundance and richness, seasonal species

\section{RESUMO}

\section{Padrões espaciais e temporais de diversidade de espécies de aves no Pantanal}

Análises de um levantamento de três anos da avifauna do Pantanal de Poconé indicam que a maioria das espécies residentes e estacionais utiliza dois ou mais tipos de habitats. Estes habitats podem ser ordenados num gradiente de riqueza de espécies e estabilidade (medida pela proporção de espécies estacionais): 1) matas - mais ricas e estáveis; 2) cerrados e pastos - intermediários; e 3) campos inundáveis/aquáticos - menos ricos e menos estáveis. Enquanto a proporção de espécies estacionais nas matas permanece relativamente constante ao longo do ano, há aumento significativo destas espécies nos outros habitats durante a estação seca. A abundância das espécies residentes parece ligada ao uso de maior variedade de habitats. São discutidas possíveis implicações decorrentes da destruição de habitats e perturbações antrópicas na conservação desta comunidade de aves.

Palavras-chave: ciclos de inundação, espécies estacionais, estabilidade de habitat, heterogeneidade de habitats, riqueza e abundância de espécies. 


\section{INTRODUCTION}

Environmental variability is part of what determines which bird species will occupy and persist in a given habitat, thereby shaping community composition and structure. In relatively stable environments, a time lag exists between climatic changes and corresponding changes in resource availability, leading to the unpredictability observed in the local dynamics of many bird communities. However, when climatic changes are extreme, changes in resource levels can be immediate and closely followed by changes in the community structure (Wiens, 1986). Extreme climatic seasonality occurs in the Pantanal of Mato Grosso, the largest flood plain in the world (Alho et al., 1988). This seasonality, in turn, results in equally extreme changes in local bird communities. The Pantanal is a rich hydrological complex within a lowland area, formed by tributaries of the Paraguay river. Large areas are covered by water during annual flooding that extends from December to May, although small land areas and some isolated hills remain above water. Different habitats, soil types, and inundation levels are responsible for the great variety of vegetation, producing a mosaic landscape (Adámoli, 1986; Rizzini, 1979; Zeilhofer \& Schessi, 1999). The cerrados, which are never flooded, are located in upland areas at the periphery of the Pantanal, while xerophytic vegetation occurs near the Chaco and on limestone formations. The rich aquatic vegetation found in the Pantanal occurs in flooded depressions, while grass fields are present in areas where the water drains away quickly (Rizzini, 1979).

Severe weather and the unpredictable duration of dry periods result in strong pressures on plant and animal populations, favoring dispersive or migratory species capable of taking advantage of the abundant, yet seasonal and transitory, resources found in the Pantanal (Brown, 1986). The presence of many plant and animal species adapted to this unpredictability support these affirmations. Many of the herbaceous plants within the flood plains die during flooding, reappearing again in the outflow period (Conceição \& Paula, 1986; Pott, 2002). As water level declines, vegetative reproduction of Salvinia auriculata (Salviniaceae) is inhibited by crowding while sporocarp production is enhanced (Coelho, 1997). During the dry season, there are local migrations of alligators (Caiman crocodilus yacare), in groups of anywhere from 3 up to 52 individuals, searching for pools of water and/or small lakes, where food is concentrated (Campos, 2002). During this period, fish gather in the rivers, form schools, migrate upstream, and reach the upper courses. Once there, at the beginning of the rainy season, they breed (Willink et al., 2000). In response to significant variation in water level and resource availability, there are also migrations of aquatic birds, such as wood storks, egrets, terns, ducks, sandpipers, hawks (e.g., snailkite), swallows, tyrant flycatchers, and many others (Antas, 1994; Oliveira, 2006; Cintra pers. obs.). However, even though the Pantanal is recognized as a threatened area of international importance for conservation, information regarding its biodiversity is still scarce and fragmented (Silva, 2002).

A recent and detailed review made by Tubelis \& Tomas $(2001 ; 2003)$ points out that researchers and collectors have surveyed the Pantanal bird fauna since the beginning of the nineteenth century. Among these, one can cite Brown (1986), who compiled the first species list. This author, who studied the origin and distribution of 658 species throughout the entire Pantanal region, concluded that the area did not favor speciation. Instead, it acts both as a dispersion corridor and barrier, as well as a breeding site for animals searching for easily found and abundant food resources. Tubelis $\&$ Tomas $(2001,2003)$ updated the species list and identified the better-known study areas, as well as the geographic locations still not scientifically investigated. In addition, they concluded (Tubelis \& Tomas, 2003) that this region contains the highest wetland-bird richness in the world: 463 species. Antas (1994) pointed out that, besides the importance of the Pantanal to wading and aquatic birds, it acts as a migration route to transitory species annually arriving from the southern part of the continent as well as from the Northern Hemisphere. The area also receives migrants from the Atlantic Forest in the eastern part of Brazil and from the pampas in the south (Silva, 1998). In addition, Cintra \& Yamashita (1990) assessed the bird fauna of the pantanal of Poconé, identifying 317 species, of which 86 occurred seasonally.

The species lists compiled by Brown (1986), Antas (1994), Tubelis \& Tomas (2001; 2003), Cintra \& Yamashita (1990), and others offer important 
data regarding the species richness and distribution in the Pantanal. However, these lists have never been statistically analyzed for the purpose of furthering what is now known of bird community dynamics in the Pantanal. The species list of Cintra \& Yamashita (1990) also included the habitat, a subjective abundance index (rare vs. common), and the period in which each species occurred. Their data offer a preliminary description of birdcommunity spatial and temporal distribution in the pantanal of Poconé.

The objective of this work was to statistically analyze this information and study it from a new, ecological perspective, in order to find patterns of bird species distribution and habitat use in the Pantanal, which could aid in future conservation efforts.

The main hypotheses are: a) use of multiple habitats by birds are a common occurrence and may be the rule in the Pantanal; b) differences in proportion between seasonal and resident species reflect habitat instability, which is higher in open habitats that are more prone to severe droughts and/or flooding; and c) cycles of seasonal species differ between bird species occurring in the uplands and those in the floodplains.

\section{METHODS}

The $15,800 \mathrm{~km}^{2}$ pantanal of Poconé is covered by a mosaic of swamps, fields, cerrado, and semideciduous and gallery forests (Allem \& Valls 1987). The region is part of the Alto Pantanal sub-area, 20\% of which is inundated for 2 to 3 months annually (Alho et al., 1988). Due to ease of access, the bird fauna surveys conducted by Cintra \& Yamashita (1990) between 1982 and 1986 were confined mainly in a particular region of the pantanal of Poconé. The authors surveyed bird species in nine habitats: semideciduous and gallery forests, cerrado, pastures, seasonally flooded fields, corixos (outlets of ponds, small lakes, or marshes), "bays", rivers, and swamps (see descriptions in Cintra \& Yamashita, 1990). Each habitat was sampled once a month for 3 years, either between $6 \mathrm{~h}$ and $9 \mathrm{~h}$ or $16 \mathrm{~h}$ and $18 \mathrm{~h}$. Sampling was conducted along $1 \mathrm{~km}$ transects on abandoned trails and roads that were traveled on for about one hour, complemented by sampling in habitat edges along the Transpantaneira Road and captures using mist nests. Rare species were those classified as seen only a few times and in small numbers; common species, as those seen frequently, and at times in groups; and seasonal species, those seen only some months out of the year. Registers of relative abundance (rare vs common) and seasonality (seasonal vs resident or number of month the species was observed) were not available for all species.

The Spearman correlation was used a) to investigate whether temporal stability of the different species (number of months of occurrence) could be explained by the number of habitats used; and b) to verify whether the species abundance (rare (0) vs. common (1)) was correlated to the number of habitats and/or to their stability through time. The dissimilarity between habitats, based on species co-occurring in each pair of habitats, was determined by comparing their Euclidian distances. A dissimilarity dendogram was generated, using the simple linkage method, i.e., the nearest neighbor distance. Species occurrences throughout the year (number of species occurring per habitat per month) were also analyzed. The relative stability of the different habitats was evaluated by dividing the number of seasonal species by that of resident ones, and also by calculating the corresponding coefficient of variation (CV) during the year. In order to minimize the error entailed by not sampling species present, a possibility when dealing with rare species, seasonality effects on abundant and rare species were analyzed separately. All analyses followed Zar (1984), using the statistical program SYSTAT 5.0. The statistical work here, by J. E. C. Figueira, was based on censuses by Cintra \& Yamashita (1990), while L. R. Viana helped with the revision, based on work in a similar ecosystem (the Everglades).

\section{RESULTS}

Of the 317 species recorded by Cintra and Yamashita (1990), 188 occurred in semideciduous forests, 164 in gallery forests, 103 in pastures, 88 in cerrado, 87 in the seasonally flooded fields, 79 in corixos, 74 in bays, 50 in swamps, and 57 in rivers. Most of the species (70\%) for which records were available occurred throughout the entire year, while the seasonal species were present from between 2 to 10 months annually (Fig. 1). 
Ninety-four percent of seasonal and resident species used 2 or more habitats (Fig. 1).

The habitat dissimilarity dendrogram generated from Table 1 separates the habitats into three groups: 1) FORESTS (semideciduous and gallery forests); 2) CERRADO (cerrado and pastures); and 3) AQUATIC (rivers, bays, swamps, corixos, and seasonally flooded fields) (Fig. 2). One hundred ninety-two species were present in the gallery and semideciduous forests, of which 160 were found in both forests. Fiftyfive species occurring in cerrado were also found in the semideciduous forests. Of these species, 44 were also found in gallery forests. Fifty-three species were present in cerrado and pastures, while 18 species were present in all aquatic habitats.

In this study, sixty-three percent of the seasonal species were considered abundant. Seasonal species comprised $16 \%$ of all species in the forests, $25-27 \%$ of those in cerrado, and $46-54 \%$ of those in the aquatic habitats (Fig. 3). The total number of seasonal species (abundant plus rare) decreases during the rainy season and increases during the dry season is shown in Fig. 4.

TABLE 1

Dissimilarity coefficients between the bird fauna from the different habitats. SWA: swamp; RIV: river; BAY: bay; COR: corixo; SFF: seasonally flooded field; PAS: pasture; CER: cerrado; GAL: gallery forest; SEM: semideciduous forest.

\begin{tabular}{|c|c|c|c|c|c|c|c|c|c|}
\cline { 2 - 10 } \multicolumn{1}{c|}{} & BAY & RIV & COR & SWA & SFF & PAS & CER & SEM & GAL \\
\hline BAY & 0.000 & - & - & - & - & - & - & - & - \\
\hline RIV & 0.323 & 0.000 & - & - & - & - & - & - & - \\
\hline COR & 0.292 & 0.398 & 0.000 & - & - & - & - & - & - \\
\hline SWA & 0.421 & 0.417 & 0.386 & 0.000 & - & - & - & - & - \\
\hline SFF & 0.369 & 0.413 & 0.382 & 0.474 & 0.000 & - & - & - & - \\
\hline PAS & 0.709 & 0.684 & 0.725 & 0.658 & 0.666 & 0.000 & - & - & - \\
\hline CER & 0.707 & 0.668 & 0.723 & 0.651 & 0.714 & 0.519 & 0.000 & - & - \\
\hline SEM & 0.871 & 0.859 & 0.888 & 0.842 & 0.919 & 0.757 & 0.725 & 0.000 & - \\
\hline GAL & 0.834 & 0.825 & 0.844 & 0.800 & 0.884 & 0.757 & 0.720 & 0.318 & 0.000 \\
\hline
\end{tabular}
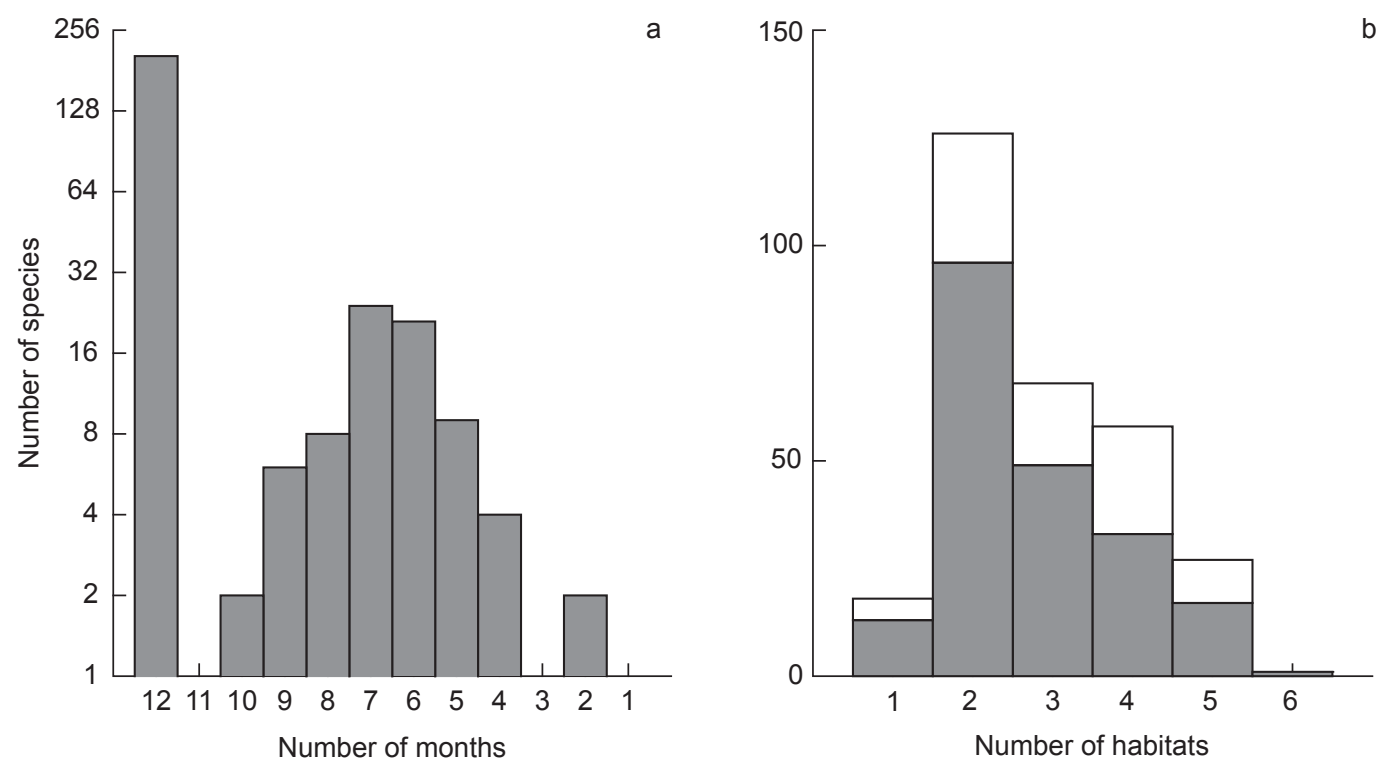

Fig. 1 - a) Number of months; and b) number of habitats in which the resident (gray bars) and seasonal species (white bars) occurred. 


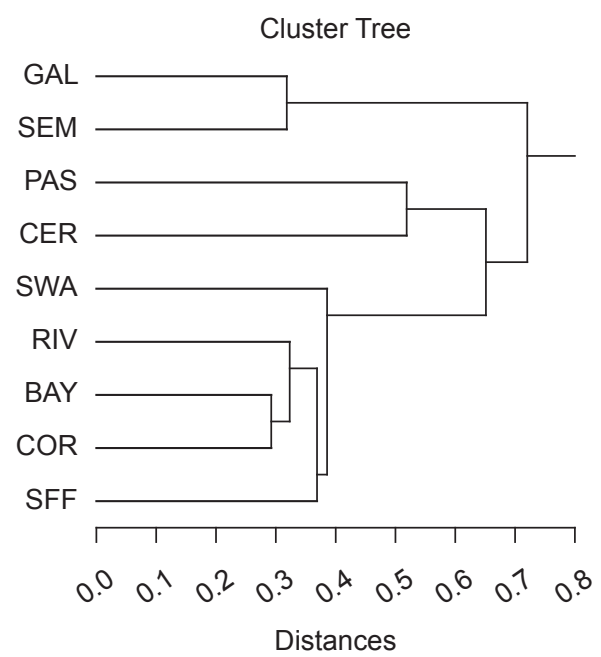

Fig. 2 - Similarities between habitats determined by their bird fauna: $\mathrm{SWA}=$ swamp, RIV = river, $\mathrm{BAY}=$ bay, $\mathrm{COR}=$ corixo, $\mathrm{SFF}=$ seasonally flooded field, PAS = pasture, CER: cerrado, GAL = gallery forest, $\mathrm{SEM}=$ semideciduous forest.

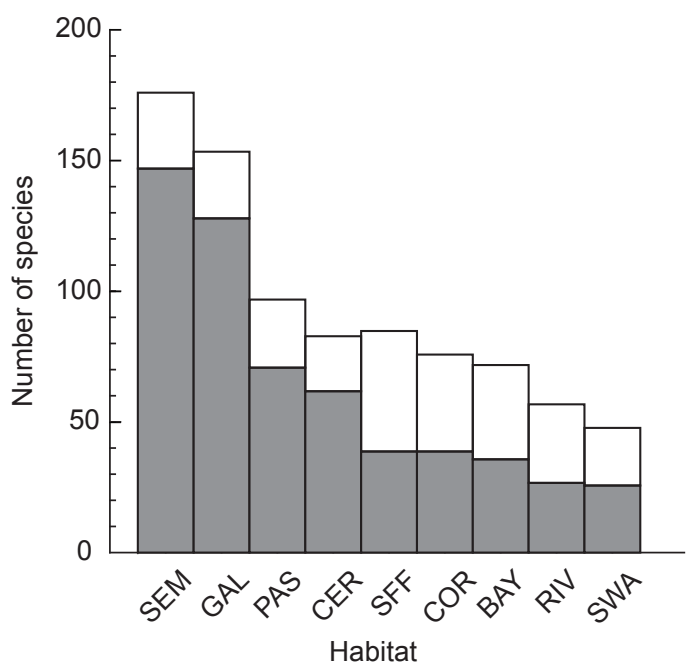

Fig. 3 - Species richness of birds in the different habitats (resident species: gray bars; seasonal species: white bars). SEM: semideciduous forest; GAL: gallery forest; PAS: pasture; CER: cerrado; SFF: seasonally flooded field; COR: corixo; BAY: bay; RIV: river; and SWA: swamp.

Variation in the forest habitats $(\mathrm{CV}=0.07)$ was smaller than in the cerrados $(\mathrm{CV}=0.24)$ and aquatic habitats $(\mathrm{CV}=0.21)$. However, this variation was accounted by species abundance $(\mathrm{CV}=0.06$, forests; 0.31, cerrado areas; and 0.19, aquatic habitats). The abundance index of the resident species correlated positively to the number of habitats used by these birds $\left(\mathrm{r}_{\mathrm{s}}=0.283, \mathrm{P}<0.005\right.$, $\mathrm{n}=209$ ). When the abundance of seasonal species was analyzed, no significant correlation was found with either the number of habitats used $\left(r_{s}=0.195, n=89, P>0.05\right)$ or the number of months in which these species were recorded $\left(r_{s}=0.172\right.$, $\mathrm{n}=77, \mathrm{P}>0.10$ ). 

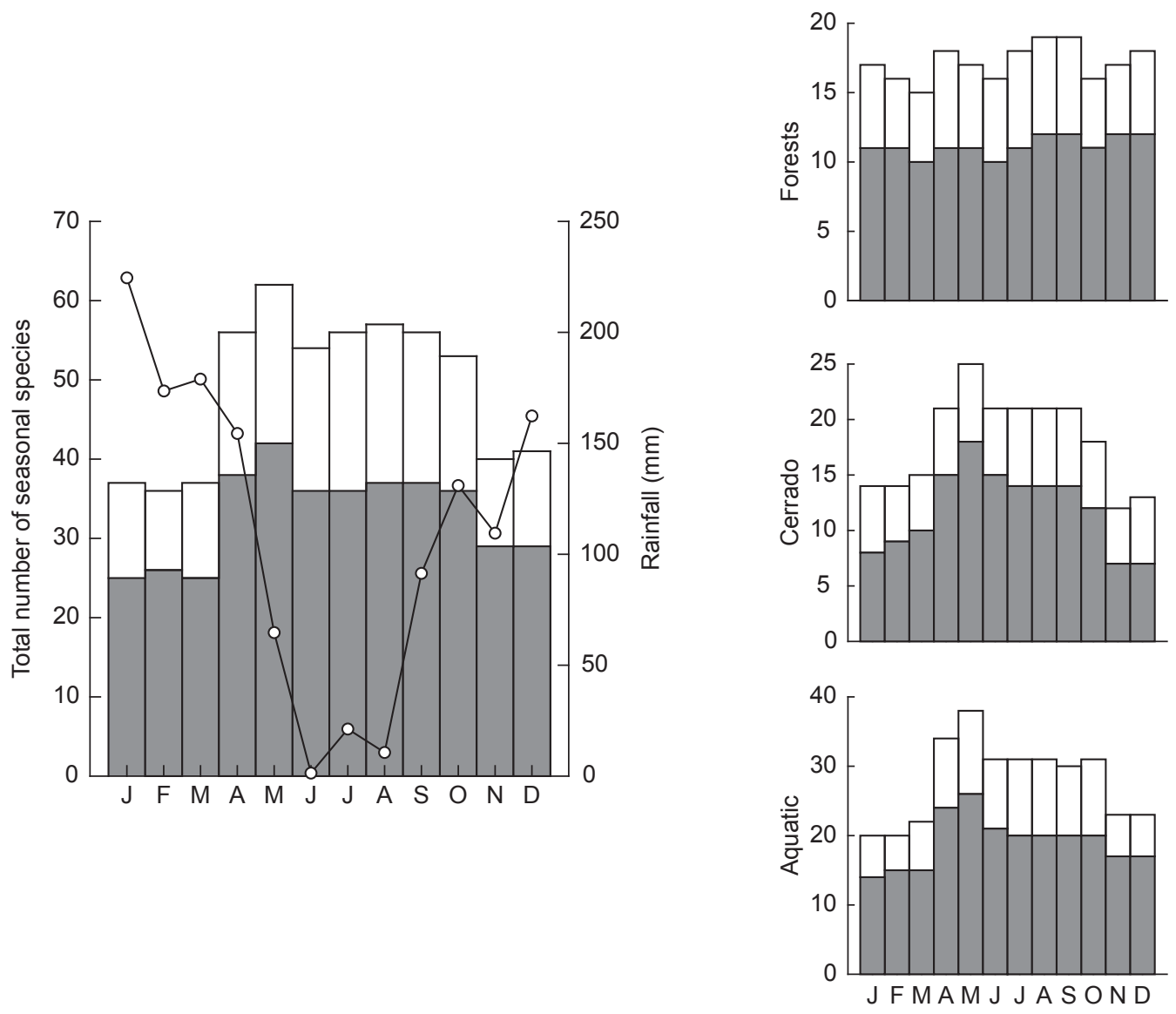

Fig. 4 - Variation in the total number of seasonal species throughout the year, showing their concentration during the dry season (common species: gray bars; rare species: white bars). The average values of precipitation are from the Cuiabá region during the 1982-1986 period. The variation in the seasonal species number is shown separately for birds from the forests, cerrado, and aquatic habitats.

\section{DISCUSSION}

In spite of the modest sampling effort in the sampling procedures used by Cintra \& Yamashita (1990), patterns of bird species occurrence in the different habitats were based on species presence or absence during the whole study, which certainly minimized errors. On the other hand, the seasonal patterns could have been more susceptible to errors entailed by lack of sampling of some species throughout the year, with the highest chances of error related to rare species. However, temporal patterns were very similar when all species were considered (rare plus abundant), or abundant species only. For this reason, the data presented in this study is believed to reflect, approximately, bird distribution within the various habitats throughout the year.

The patterns observed suggest that the structure and dynamics of the Pantanal bird community are strongly linked to environmental heterogeneity and flooding cycles. Furthermore, they corroborate the hypothesis that transient, generalist species are favored within the temporally variable and patchy habitats occurring in the Pantanal. Cunha et al. (2002) pointed out the importance of environmental heterogeneity to fauna: different landscape units may function as dispersion corridors, stepping-stones, refuges, and feeding sites in the Pantanal. Brown (1986) observed that climate and resource instability and the abundance of large generalist predators in the floodplains favored large, mobile individuals, 
resistant to long dry periods and associated with aquatic environments. Besides that, cold fronts that periodically occur in the Pantanal during July and August could favor omnivorous species (Willis, 1976). In addition, the quantity of fish in the Pantanal, which is among the greatest on the planet (Conceição \& Paula, 1986), partially explains the present regional abundance of aquatic birds.

Brown (1986) considers the Pantanal a dispersion corridor rather than a speciation center, a view supported by a sampling conducted by Cintra \& Yamashita (1990), which found no endemic species. According to Brown (1986), 60\% of Pantanal bird species are broadly distributed, and composed of $20 \%$ aquatic species, $40 \%$ from open environments (cerrado and Chaco), and 30\% from other forests (the Amazon and Atlantic). Although not updated (see Tubelis \& Tomas, 2003), Brown's bird list (1986) clearly shows the importance of environmental heterogeneity in determining species diversity in the Pantanal. Similarly, the gallery and semideciduous forests in the pantanal of Poconé host a higher number of forest-dependent or semi-dependent bird species, thus reinforcing the importance of these vegetation types in increasing local bird diversity in the Pantanal. This was also observed for birds and mammals in the cerrado region (Negret \& Negret, 1981; Negret et al., 1984; Silva, 1995). The gallery forests among the cerrado areas function as mesic corridors, providing suitable habitats and increasing the geographic extension of birds and mammals that are essentially of forest environments. Accordingly, species from the Amazon and Atlantic Forest are also found in the cerrado fauna (Silva, 1995; Redford \& Fonseca, 1986). A total of $44 \%$ of the birds from the Brazilian cerrado areas (366 species) depend totally or partially on forests (Silva, 1995). Considered key areas for maintaining bird fauna diversity (Silva, 1995; Silva \& Bates, 2002), these areas offer refuge, food, and water to mammals, birds, and other non-resident animals (Medellin \& Redford, 1992; Ribeiro et al., 2002). Forests become especially important during the dry period and occasional drought years, as well as during fire periods, when they function as refuges and sources of dispersing re-colonizers (Cavalcante, 1992; Redford \& Fonseca, 1986). Ecotones and forest edges also appear important in supporting populations of some cerrado bird species that would otherwise be forced to migrate elsewhere. This is the case for some bird species that depend on seasonal resources, e.g., fruits and flowers, as well as species that take advantage of different resources that become sporadically available in cerrado areas and along the forest edges (Cavalcanti, 1992; Lins, 1994), such as tinamous, pigeons, doves, macaws, parrots, hummingbirds, tyrant-flycatchers, thrushes, caciques, warblers, tanagers, and seedeaters. In Poconé, bird similarity in cerrado areas resembles more that of pastures, although pastures are structurally more like seasonally flooded fields. The difference is that agriculture and orchards occur in pastures while murundus (patches of non-floodable shrubs and trees) (Oliveira-Filho, 1992a, b) occur in the flooded fields (Cintra \& Yamashita, 1990). This supports Stotz et al. (1996), who observed that few grassland bird species tolerate agricultural areas or pastures, while the many species found in their study originated from nearby habitats with shrub vegetation, recovering forests, or woodedarea edges. However, the seasonally flooded fields, when periodically submersed, allow for aquatic bird occurrence, which results in a higher species-composition similarity with other aquatic environments.

Aquatic birds showed less habitat preference than all other species, and that their aquatic habitats can be described as fine-grained (Ricklefs, 1990) is suggested by the fact that they present many bird species in common. However, according to Stotz et al. (1996), birds are not good indicators of aquatic environmental conditions, because they occur in multiple habitats and are often more influenced by conditions around water bodies than conditions within them.

Habitat specialization in birds is measured by the number of habitats they use (Stotz et al., 1996). The data from Cintra \& Yamashita (1990) suggest that as a rule bird fauna, resident species as well as seasonal, from the pantanal of Poconé occur in different habitats. In relation to habitat sharing by species, this reflects ecological flexibility and/ or similarities among these habitats regarding structure, microclimate, food availability, and refuge conditions. Habitat sharing also indirectly indicates the potential flux of individuals and species between different habitats and, consequently, the complexity, interconnectedness, and flexibility of interactions in a trophic web. Habitat heterogeneity 
in space and time is, therefore, fundamental not only to increasing, but also to maintaining local diversity of aquatic and terrestrial birds. According to Wilson \& Willis (1975), the persistence of certain species is favored by ecologically appropriate habitat patches that allow reciprocal intercolonization events through time, which could potentially trigger metapopulational dynamics (Levins, 1969).

Habitat specialist birds represent only $6.3 \%$ of the total number of species identified in the pantanal of Poconé. None of these, which are generally rare and of open habitats (Cintra \& Yamashita, 1990), are on the Brazilian endangered species list (CEMAVE, 2004). The positive correlation observed between abundance and the number of habitats used by resident species suggests that abundance is determined by the capacity to tolerate different environmental conditions and/or to exploit a greater variety of resources. Furthermore, ecologically more flexible resident species appear more able to maintain larger populations (see alternative hypothesis in Hanski et al., 1993). Conversely, the lack of correlation between abundance of seasonal species and the number of habitats they use suggests that, contrary to that of resident species, seasonal species abundance is not determined by capacity to occupy and/or to exploit habitats. In addition, no correlation was found between abundance and the number of months in which seasonal species occurred, suggesting that seasonal species abundance is not contingent on the stability of resources through time.

The Pantanal flooding cycle is annual. However, there are multiyear cycles in which severe flooding and droughts occur (Cunha et al., 2002). During these events fauna invade the floodplains from more stable and safer, non-flooding habitats, creating sporadic but ephemeral populational increases (Brown, 1986; see also Antas, 1994; and the recent results of Oliveira (2006)). As a group, different seasonal birds occurred in forest, cerrado, and aquatic habitats in both rainy and dry periods of the year, suggesting that for the pantanal of Poconé no optimal period exists for all seasonal species.

For habitat stability, a ranked gradient based on the proportion of seasonal to resident species was determined. Forest areas proved more stable than those of cerrado (in agreement with Lins, 1994, for birds from gallery forests within the cerrado), which in turn were more stable than the aquatic habitats. This pattern is partially confirmed by the monthly variations in the seasonal species number (forests $>$ aquatic $>$ cerrado).

Migration is pronounced among aquatic birds: $35 \%$ of the species using freshwater habitats and reproducing in the Neotropics are migratory and, even among resident species, many move regularly responding to water level or resource availability fluctuations (Stotz et al., 1996). The temporal patterns observed in the present work indicate that most aquatic bird migrations from the pantanal of Poconé coincide with the beginning of the rainy period, while the return occurs during the dry period. This supports an observation of Antas (1994), to the effect that many migratory aquatic birds leave the Pantanal (heading for the humid areas of Rio Grande do Sul and Vale do Rio Paraná) during flooding. The dry period provides greater quantities of fish, amphibians, mussels, snails, crabs, insect larvae, and other aquatic invertebrates that can easily be captured when water levels fall, as many of these organisms are caught in pools or mud (see also Antas, 1994; Silva et al., 2002). Oliveira (2006) found that the abundance of aquatic birds increases as the amount of rain (pluviosity) decreases in the Pantanal of Poconé.

Even with the possibility of using other nearby habitats during the non-favorable periods, $27 \%$ of the birds identified in cerrado of the pantanal of Poconé still occur only seasonally. However, contrary to what had been expected, these seasonal species become more abundant specially during the dry season, when resources are expected to be scarcer. This increase in abundance could be because birds in nearby habitats have few or no established territories during the dry period and so expand their home ranges into adjacent habitats, including temporary presence in the cerrado (suggested by Coelho (2000) for birds of small Atlantic forest fragments). On the other hand, the number of seasonal species in the forests is lower and seasonality is less distinct than that found in the cerrado and aquatic environments, thus suggesting more predictable resource availability throughout the year. Observations made by Cavalcanti (1992) indicate that gallery forests support a bird fauna different from that of cerrado, with a greater number of resident species, some of which use cerrado seasonally, specially during the rainy 
periods when winged termites and fruits become abundant. The forests and other non-floodable vegetation patches allow occurrence of organisms not tolerant to floods, thus considerably increasing local biodiversity (Cunha et al., 2002).

Temporal variations observed in bird communities should reflect a dynamic balance occurring in two ways: a) individuals in populations and communities closely following variations in resource availability, through short-term adjustments in their behavior, demography, and distribution; and b) individuals in populations and communities not closely following the variations in resource availability brought about by periods of severe climate or resource depletion, alternating with periods of resource superabundance (Wiens, 1994). Data from the present work suggest that, in the Pantanal bird community, these two strategies occur. Therefore, resident species would try to find necessary resources in different habitats to compensate for availability fluctuations, while the seasonal species would abandon the area cyclically.

Many have suggested the Pantanal of Mato Grosso as a region for establishing conservation reserves (Fundação Pró-Natureza, Conservation International, Fundação Biodivérsitas, Universidade de Brasília, 2000; Wege \& Long, 1995). However, current as well as pending anthropic impacts are already reducing habitat diversity and threatening to alter flooding cycles. Alho \& Vieira (1997), Alho et al. (1988), and Mittermeier et al. (1990) have alerted the public to an increase in agricultural areas, deforestation, and gold-mining, consequent loss to species of food and refuge sites, and rising numbers of fish and aquatic birds (like cormorant, snail kite, and limpkin) presenting high mercury levels. To cite just one cause for concern, widespread deforestation can also interfere with bird migration from seasonally dry environments (Willis \& Oniki, 1990). Severe impacts are also foreseen resulting from the construction of dams along the Paraguay river (and, if implemented, with Paraná-Paraguay waterway dredging), which could alter the seasonal flood regime (Antas, 1994). This alteration in flood regime could impact diverse vegetation forms, many of which within the Pantanal are sensitive to flooding. While some, such as the canjiqueira are capable of expanding during the dry season others, like the cambarazal may retreat (see
Silva et al., 2002). In the Everglades, vegetative islands similar to those found in the Pantanal and that are also sensitive to flooding are disappearing due to water level increase and an increased period of inundation caused by water management. These islands are important since they serve as biodiversity centers, and provide refuge and nesting sites for fauna from nearby flooded areas (USGS, 2003). Man-made fires can also be detrimental because they can cause abnormal migratory movements (Alho et al., 1988). Besides these impacts, cities in the region are growing quickly and floodable areas have been drained for agricultural purposes (Stotz et al., 1996).

Aquatic and woodland habitat divisions into several sub-habitats (Cintra \& Yamashita, 1990) may artificially decrease the apparent susceptibility of Pantanal bird species to human occupation, seeming to induce a wider ecological flexibility in habitat use, including by the apparently more generalist aquatic birds. However, several species require specific resources, habitat types, and/or specific environmental conditions. Therefore, changes in flooding cycle and the destruction of alternative key resources/habitats can, besides lowering population numbers, also cause species loss. For instance, most shorebird species need shallow water habitats covered with sparse vegetation, adequate amounts of mudflats, and sufficient invertebrate populations (Davis \& Smith, 1998; Isola et al., 2000). Wading birds, such as herons and storks, need a series of drying ponds spatially and temporally spread out in which to prey on concentrated fish resources (Kushlan, 1976; Silva et al., 2000). Colonies of these birds also need patches of woods composed of trees resistant to flooding, such as Crataeva pavia and Albizia polyantha, in order to build nests. When these birds leave the region during the flooding period, they are replaced by cormorants and anhingas that forage in deeper waters (Silva et al., 2002). In Florida, nesting initiation, production, and survival of young in wood storks (Mycteria americana) was related to seasonal fluctuations in the water level (Clark, 1978). The gallinule Porphyrula martinica disappeared from a lake in southeastern Brazil because the cat-tail swamps that it occupied in the shade at midday, and in which it made its nests, were cleared, even though early and later feeding 
sites in the day still remained intact and even increased (Willis, 2003).

The prey specialist snail kite (Rosthramus sociabilis) can also be threatened by the elimination of aquatic plants that harbor one of its main food items, the snail Pomacea (Sick, 1984). Also, the trees Ficus calyptroceras and Erythrina dominguezzi of deciduous forests in the western Pantanal provide parrots, parakeet, toucans, and several other bird species with a remarkable supply of fruits and nectar, especially in the dry season, a period of generalized food scarcity (Ragusa-Netto, 2002a; b). In the Pantanal the very specialized hyacinthine macaw (Anodorhynchus hyacinthinus) feeds only on the fruits of the palm trees Acromia aculeata, and Attalea phalerata. The Sterculia apetala tree, its primary nesting site, has been destroyed by windstorms and fire (Guedes 1993, Johnson et al., 1997). These examples point to a much more complex type of habitat dependency then that suggested for generalist species. Therefore, within the Pantanal, although many species may be habitat generalists those habitats may not be perfectly interchangeable, so that each habitat could be providing its own crucial key resources, suggesting the importance of protecting as many different types of habitats as possible in order to maintain the high levels observed of species diversity. This would be in accordance with an observation of Law \& Dickman (1998): "the requirement by many species for multiple habitats suggests that their conservation will be most effective in a mosaic environment and that protection of certain high profile habitats alone will be insufficient to achieve conservation goals".

The observed patterns in the present work are mainly suggestive, and should be interpreted cautiously. However, they indicate that the Pantanal is an extremely complex and dynamic ecosystem spatiotemporally. These patterns also underscore the need for an extensive regional-level preservation effort aimed at maintaining the different landscape units, as well as the seasonal flood cycles that determine the structure and dynamics of their ecological communities.

Acknowledgments - We would like to thank Prof. Marcos Rodrigues, Prof. Anthony Brome Rylands (Departamento de Zoologia - UFMG), and Prof. Edwin Willis for their critical reviews, suggestions, and/or encouragement. Thanks to Dr. Dalci de Oliveira for sharing his knowledgments on birds of Pantanal. IBAMA provided logistic support at its Base of Research in the
Pantanal of Poconé. The Pantaneiros Estelito Carvalho, Oelio Falcão, Leire Falcão, Tito Correia (in Memorian), Tutu, Ditinho were competent field guides and assistants in the area.

\section{REFERENCES}

ADÁMOLI, J., 1986, Fitogeografia do Pantanal. pp. 105-107. In: Anais do $1^{\circ}$ Simpósio Sobre Recursos Naturais e Sócioeconômicos do Pantanal. EMBRAPA-CPAP. Brasília.

ALHO, C. J. R., LACHER JR., T. E. \& GONÇALVES, H. C., 1988, Environmental degradation in the Pantanal Ecosystem. BioScience, 38: 164-171.

ALHO, C. J. R. \& VIEIRA, L. M., 1997, Fish and wildlife resources in the Pantanal wetlands of Brazil and potential disturbances from release of environmental contaminants. Environ. Toxicol. Chem., 16: 71-74.

ALLEM, A. C. \& VALLS, J. F. M., 1987, Recursos Forrageiros Nativos do Pantanal Mato-Grossense. EMBRAPA, Brasília, 339p.

ANTAS, P. T. Z., 1994, Migration and other movements among the lower Paraná River valley wetlands, Argentina, and the south Brazil/Pantanal wetlands. Bird Conserv. Intern., 4: 181-190.

BROWN, JR. K. S., 1986, Zoogeografia da região do Pantanal Mato-Grossense. pp. 137-178. In: Anais do $1^{\circ}$ Simpósio Sobre Recursos Naturais e Sócio-econômicos do Pantanal. EMBRAPA-CPAP, Brasília.

CAMPOS, Z. M. S., 2002, Comportamento de termorregulação, movimento, área de uso e suas implicações para o manejo do jacaré-do-pantanal (Caiman crocodilus yacare). Tese de Doutorado, Pós-Graduacao em Ecologia, Conservação e Manejo da Vida Silvestre - UFMG, Belo Horizonte.

CAVALCANTI, R. B., 1992, The importance of forest edges in the ecology of open country cerrado birds. pp. 513-518. In: P. A. Furley, J. Proctor \& J. A. Ratter (eds.). Nature and Dynamics of Forest-Savanna Boundaries. Chapman \& Hall, London.

CEMAVE, 2004, Nova Lista das Aves Brasileiras Ameaçadas de Extinção. http://www2.ibama.gov.br/cemave/.

CINTRA, R. \& YAMASHITA, C., 1990, Habitats, abundancia e ocorrência das espécies de aves do Pantanal de Poconé, Mato Grosso do Sul, Brasil. Papéis Avul. Zool., 37: 1-21.

CLARK, E. S., 1978, Factor affecting the initiation and success of nesting in an East-Central Florida wood stork colony, pp. 178-183. In: Proceedings Colonial Waterbird Group. 1978 Conference, The American Museum of Natural History, New York.

COELHO F. F., 1997, Estratégias reprodutivas de Salvinia auriculata Aublet (Pteridophyta) no Pantanal do MirandaAbobral, Mato Grosso do Sul. Tese de Mestrado Universidade Federal de Mato Grosso do Sul.

COELHO, M. M., 2000, Efeitos da fragmentação florestal em bandos mistos de aves de Mata Atlântica, no Sudeste de Minas Gerais. Tese de Mestrado. Instituto de Ciências Biológicas, Universidade Federal de Minas Gerais, Belo Horizonte.

CONCEIÇÃO, C. A. \& PAULA, J. E., 1986, Contribuição para o conhecimento da flora do Pantanal Mato-Grossense e sua 
relação com a fauna e o homem, pp. 107-130. In: Anais do 1o Simpósio Sobre Recursos Naturais e Sócio-econômicos do Pantanal. EMBRAPA-CPAP. Brasília.

CUNHA, C. N., JUNK, W. J. \& SILVEIRA, E. A., 2002, A importância da diversidade de paisagem e da diversidade arbórea para a conservação do Pantanal, pp. 71-76. In: E. L. Araújo, A. N. Moura, E. V. S. B. Sampaio, L. M. S. Gestinari \& J. M. T. Carneiro (eds.) Biodiversidade, Conservação e Uso Sustentado da Flora do Brasil. UFPE, Imprensa Universitária, Pernambuco.

DAVIS, G. A. \& SMITH, L. M., 1998, Ecology and management of migrant shorebirds in the Playa Lakes Region of Texas. Wildl. Monogr., 140: 1-45.

FUNDAÇÃO PRÓ-NATUREZA, CONSERVATION INTERNATIONAL, FUNDAÇÃO BIODIVÉRSITAS, UNIVERSIDADE DE BRAŚÍLIA 2000, Avaliação $e$ Ações Prioritárias para a Conservação da Biodiversidade do Cerrado e Pantanal. Brasília: MMA/ SBF.

GUEDES, N. M. R., 1993, Biologia reprodutiva da arara-azul (Anordorhynchus hyacinthinus) no Pantanal-MS, Brasil. Tese de Mestrado, Esalq-USP.

HANSKI I., KOUKI, J. \& HALKKA, A., 1993, Three explanations of the positive relationship between distribution and abundance of species, pp. 108-116. In: Ricklefs, R. E. \& D. Schluter (eds.) Species Diversity in Ecological Communities. The University of Chicago Press, Chicago.

ISOLA, C. R., COLWELL, M. A., TAFT, O. W., \& SAFRAN, R. J., 2000, Interspecific differences in habitat use of shorebirds and waterfowl foraging in managed wetlands of California's San Joaquin Valley. Waterbirds, 23: 147-336.

JOHNSON, M. A., TOMAS, W. M. \& GUEDES, N. M. R., 1997, Density of young manduvi (Sterculia apetala), the Hyacinthine Macaw's nesting tree, under three different management conditions in the Pantanal wetland, Brazil. Ararajuba, 5: 185-188.

KUSHLAN, J. A. 1976. Wading bird predation in a seasonally fluctuating pond. Auk, 93:464-476.

LAW, B. S. \& DICKMAN, C. R., 1998, The use of habitat mosaics by terrestrial vertebrate fauna: implications for conservation and management. Biodiv. Conserv., 7: $323-333$

LEVINS, R., 1969, Some demographic and genetic consequences of environmental heterogeneity for biological control. Bul. Entomol. Soc. Am., 15: 237-240.

LINS, L. V., 1994, O papel da mata ciliar na estrutura de uma comunidade de aves do cerrado (Brasília, DF). Tese de Mestrado. Instituto de Ciências Biológicas, Universidade Federal de Minas Gerais, Belo Horizonte.

MEDELLIN, R. A. \& REDFORD, K. H., 1992, The role of mammals in neotropical forest-savanna boundaries, pp. 519-548. In: Furley P.A., J. Proctor \& J.A. Ratter (eds.). Nature and Dynamics of Forest-Savanna Boundaries. Chapman \& Hall, London.

MITTERMEIER, R. A., CÂMARA, I. G., PÁDUA, M. T. J. \& BLANCK, J., 1990, Conservation in the Pantanal of Brazil. Oryx, 24: 103-112.
NEGRET, A \& NEGRET, R., 1981, As aves migratórias do Distrito Federal. Bol. Técnico n ${ }^{\circ} 6$ IBDF.

NEGRET, A., TAYLOR J., CINTRA R., CAVALCANTI R. \& JOHNSON C., 1984, Aves da região geopolítica do Distrito Federal- Lista (check list) 429 espécies. SEMA, MINTER.

OLIVEIRA, D. M. 2006. Efeitos bióticos e abióticos de ambientes alagáveis nas assembléias de aves aquáticas e piscívoras no Pantanal, Brasil. PhD Thesis. Universidade do Amazonas/Instituto Nacional de Pesquisas da Amazônia, Manaus, AM, 198p.

OLIVEIRA-FILHO, A. T., 1992a, Floodplain "murundus" of Central Brazil: Evidence for the termite-origin hypothesis. J. Trop. Ecol., 8: 1-19.

OLIVEIRA-FILHO, A. T., 1992b, The vegetation of Brazilian "murundus": The island-effect on the plant community. J. Trop.Ecol., 8: 465-486.

POTT, V. J., 2002, A importância das plantas aquáticas para a conservação do Pantanal, pp. 77-80. In: E. L. Araújo, A. N. Moura, E. V. S. B. Sampaio, L. M. S. Gestinari \& J. M. T. Carneiro (eds.) Biodiversidade, Conservação e Uso Sustentado da Flora do Brasil. UFPE, Imprensa Universitária, Pernambuco.

RAGUSA-NETTO, J., 2002a, Fruiting phenology and consumption by birds in Ficus calyptroceras (Miq.) Miq. (Moraceae). Braz. J. Biol., 62: 339-346.

RAGUSA-NETTO, J., 2002b, Exploitation of Erythrina dominguezii Hassl. (Fabaceae) nectar by perching birds in a dry forest in western Brazil. Braz. J. Biol., 62: 877-883.

REDFORD, K. \& FONSECA, G. A. B., 1986, The role of gallery forests in the zoogeography of the cerrado's nonvolant mammalian fauna. Biotropica, 18: 126-135.

RIBEIRO, J. F., FELFILI, J. M. \& SOUSA-SILVA, J. C., 2002, Biodiversidade das matas ribeirinhas no Bioma Cerrado, pp. 62-67. In: E. L. Araújo, A. N. Moura, E. V. S. B. Sampaio, L. M. S. Gestinari \& J. M. T. Carneiro (eds.) Biodiversidade, Conservação e Uso Sustentado da Flora do Brasil. UFPE, Imprensa Universitária, Pernambuco

RICKLEFS, R. E., 1990, Ecology. W. H. Freeman and Company, New York, 896p.

RIZZINI, C. T., 1979, Tratado de Fitogeografia do Brasil. HUCITEC and EDUSP. São Paulo, 747p.

SICK, H., 1984, Ornitologia Brasileira, $2^{\circ}$ vol., Editora Universidade de Brasília, Brasília, 481p.

SILVA, C. J., AGUIAR-ABDO, M. S., OLIVEIRA, D. M. M. \& GIRARD, P., 2002, Caraterização ambiental do ninhal Corutuba, Pantanal de Barão de Melgaço, MT. In: Empresa Brasileira de Pesquisa Agropecuária (EMBRAPA-CPAP) (ed.): Anais do III Simpósio sobre Recursos Naturais e Sócio-Econômicos do Pantanal, Corumbá, Brasil, November 27-30, 2000.

SILVA, C. J., 2002, Políticas e programas de conservação para o Pantanal, pp. 68-70. In: E. L. Araújo, A. N. Moura, E. V. S. B. Sampaio, L. M. S. Gestinari \& J. M. T. Carneiro (eds.) Biodiversidade, Conservação e Uso Sustentado da Flora do Brasil. UFPE, Imprensa Universitária, Pernambuco.

SILVA, J. M. C., 1995, Birds of the Cerrado Region, South America. Steenstrupia, 21: 69-92. 
SILVA, J. M. C., 1998, Ações prioritárias para a conservação do Cerrado e Pantanal. Workshop. FUNATURA, CI-Brasil, Biodivérsitas, UNB.

SILVA, J. M. C. \& BATES, J. M., 2002, Biogeographic patterns and conservation in the South American Cerrado: a Tropical Savanna Hotspot. BioScience, 52: 225-233.

STOTZ, D. F, FITZPATRICK, J. W., PARKER III, T. A. \& MOSKOVITS, D. K., 1996, Neotropical Birds. Ecology and Conservation. The University of Chicago Press, Chicago, 478p.

TUBELIS, D. P. \& TOMAS, W., 2001, Revisão e atualização da listagem de espécies de aves registradas na planície do Pantanal. In: Anais do III Simpósio sobre Recursos Naturais e Sócio Econômicos do Pantanal. CD-Rom, EMBRAPA, Corumbá.

TUBELIS, D. P. \& TOMAS, W., 2003, Bird species of the Pantanal wetland, Brazil. Ararajuba, 11: 5-37.

USGS 2003, Tree Islands of the Florida Everglades - A Disappearing Resource. http://sofia.er.usgs.gov/publications/ofr/03-26/.

WEGE, D. C. \& LONG, A. J., 1995, Key Areas for Threatened Birds in the Neotropics.Cambridge, Birdlife International, The Burlington Press Ltd., 311p.

WIENS, J. A., 1994, The Ecology of Bird Communities: Processes and Variations. Cambridge University Press, Cambridge, 316p.

WIENS, J. A., 1986, Spatial scale and temporal variation in studies of shrubsteppe birds, pp. 154-172. In: J. Diamond \& T. J. Case (eds.) Community Ecology. Harper \& Row, New York.
WILLINK, P., FROEHLICH, O., MACHADO-ALLISON, A., MENEZES, N., OYAKAWA, O., CATELlA, A., CHERNOFF, B., LIMA, F. C. T., TOLEDO-PIZA, M., ORTEGA, H, ZANATA, A. M. \& BARRIGA, R., 2000, Fishes of the Rios Negro, Negrinho, Taboco, Aquidauana, Taquari and Miranda, Pantanal, Brasil: Diversity, Distribution, Critical Habitats and Value, pp. 63-81. In: P. W. Willink, B. Chernoff, L.E. Alonso, J. R. Montambault, \& R. Lourival 2000. A Biological assessment of the Aquatic Ecosystems of the Pantanal, Mato Grosso do Sul, Brasil. RAP Bulletin of Biological Assessment \# 18. Conservation International.

WILLIS, E. O., 1976, Effects of a cold wave on an Amazonian avifauna in the upper Paraguay drainage, western Mato Grosso, and suggestions on oscine-suboscine relationships. Acta Amaz., 6: 379-394.

WILLIS, E. O. \& ONIKI, Y., 1990, Levantamento preliminar das aves de inverno em dez áreas do sudoeste de Mato Grosso, Brasil. Ararajuba 1: 19-38.

WILLIS, E. O., 2003, Birds of a eucalyptus woodlot in interior São Paulo. Braz. J. Biol., 63: 141-158.

WILSON, E. O.\& WILLIS, E. O., 1975, Applied Biogeography, pp. 522-534. In: M. L. Cody \& J. M. Diamond (eds.) Ecology and Evolution of Communities. Belknap Press of Harvard University Press, Cambridge.

ZAR, J. H., 1984, Biostatistical Analysis. Prentice-Hall, New Jersey, 736p.

ZEILHOFER, P. \& SCHESSI, M., 1999, Relationship between vegetation and environmental conditions in the northern Pantanal of Mato Grosso, Brazil. J. Biogeogr., 27: $159-168$ 